\title{
Impact of Yeast Foliar Application on The Growth of Maize Intercropped with Peanut Irrigated with Saline Water
}

\author{
M. G. Attia and A. A. M. El-Araby \\ Soil Salinity \& Alkalinity Research Department- Soils, Water \& Environment Research \\ Institute- Agricultural Research Center (ARC), Alexandria, Egypt.
}

\begin{abstract}
The present study was carried out to evaluate the effects of foliar application of Saccharomyces cerevisiae (yeast) on vegetative growth of the sole and intercropped maize and peanut plants grown under irrigation with saline water. This trial was initiated in Soil Salinity \& Alkalinity Research Department at Alexandria, Egypt in 2014. A 3-way factorial experiment based on a completely randomized block design, with three replicates was used. The treatments are comprised of three water salinity levels $(0,4$, and $8 \mathrm{dS} / \mathrm{m})$, three different cropping system (maize, peanut and maize-peanut intercropped) and 2 foliar yeast applications. Agronomic traits, including plant height, shoot dry weight, cob weight, grain yield, and weight of 100 seeds were recorded. Increasing salinity levels up to $8 \mathrm{dS} / \mathrm{m}$ decreased the seeds weight of corn to $56.03 \%$ and decreased the grain weight of peanut to $45.06 \%$ as compared with control treatment. With respect to the cropping system, intercropping was primitive to induce higher yields than sole plants confirming the positive effect of intercropped corn with peanut. Spraying plants with yeast increased the yield of peanut plants than maize ones.
\end{abstract}

Keywords: Salinity - Intercropped - Yeast - Peanut - Maize

\section{INTRODUCTION}

In arid and semiarid regions, different problems are commonly prevail due to the deficit of the irrigation water supply and salinity hazard under such condition. Plants are generally suffering from severe nutritional imbalance, retardation of plant growth, associated with reduction in yield potentials. Selfsustaining, low-input, and energy-efficient agricultural systems in this context are being in the center of attention of many farmers, researchers and policy makers worldwide (Altieri, 1999). Intercropping and the agricultural practice of cultivating two or more crops in the same space at the same time are well known as cropping practice which aims to match efficiently crop demands to the available growth resources and labor (Lithourgidis et al., 2011). The most common goal of intercropping is to produce greater yields on a given agricultural area (Ouma and Jeruto 2010). Intercropping system has benefits in maximize the use of agricultural factors such as water, area, light and nutrients (Li et al., 2003), as well as to amendment crop quality and quantity (Mpairwe et al., 2002). Moreira (1989) stated that mixed cropping especially with legumes can betterment both forage quality and quantity because legumes are well source of protein.

Bio-fertilizers are formulations of beneficial microorganisms, which upon application can increase the availability of nutrients by their biological activity and help to improve the soil health (Agamy et al., 2013). In addition, biofertilizers are generally characterized by low cost prices and very effective for providing surplus nutritional supply, as compared with chemical fertilizers (Boraste et al., 2009). In addition to their role in enhancing the growth of the plants, biofertilizers can act as biocontrol agents in the rhizosphere at the same

Vol. 21(1), 2016 
time. This synergistic effect, when present, increases the role of application of bio-fertilizers in the sustainable agriculture (Agamy et al., 2013). The use of yeast as a bio-fertilizer in agriculture is now receiving considerable attention, because they synthesize antimicrobial and other useful substances required for plant growth from amino acids and sugars secreted by bacteria, organic matter and plant roots (Boraste et al., 2009). Saccharomyces cerevisiae is, recently, introduced as a new promising plant growth promoting yeast for different crops. Its application is being practiced as an alternative mean for the chemical fertilizers, safely used for human, animal and environment (Omran, 2000). Most of the studies indicate that plant root growth may be directly or indirectly enhanced by yeasts in the rhizosphere (Nassar et al., 2005, El-Tarabily and Sivasithamparam, 2006 and Cloete et al., 2009). Representatives of Saccharomyces is able to nitrify ammonium to nitrate via nitrite in vitro (Al-Falih, 2006) and oxidize elemental sulfur in vitro to produce tetrathionate, and sulfate (Al- Falih and Wainwright, 1995).

The objective of this study is being proposed to investigate the effect of foliar application of yeast (Saccharomyces cerevisiae) on the tolerance of maize (Zea mays) and peanut (Arachis hypogaea) either sole or intercropped together grown under irrigation with saline water.

\section{MATERIALS AND METHODS}

This study was carried out at Soil Salinity and Alkalinity Research Department in Alexandria, Egypt from June to September 2014. The experiment was carried out in sandy soil plots $\left(1 \mathrm{~m}^{2}\right)$. The Physical and chemical properties of soil were determined (Table 1) according to the methods described by Richards (1954) and Watanabe \& Olsen (1965) and Page (1982) and BlacK (1965) and Bouyoucos ( 1951). A 3-way factorial experiment was planned on randomized complete block design with three replicates was employed. Basically the seeds of peanut (Grilly) and maize (single cross Giza 176) were provided from the Crop Research Institute, Agricultural Research Center (ARC) - Giza, Egypt. Treatments were consisted of 3 levels $\left(0,4\right.$ and $\left.8 \mathrm{dSm}^{-1}\right)$ of saline water ( $\mathrm{NaCl}$ solution), 3 cropping system (sole maize, sole peanut and maize/peanut intercropped) and 2 foliar yeast extract; half of the plants were subjected to yeast foliar spray monthly during the growing season ( 3 times) and the rest was untreated to be used for the relative comparison.

Maize and peanut seeds were sown, keeping the plant density of sole maize and sole peanut at 7 and $40 \mathrm{~kg} / \mathrm{fed}$, respectively. In maize/peanut intercropping system, one-half of the population density was used.

The yeast inoculum was prepared as follow: $200 \mathrm{~g}$ of yeast (produced by Alexandria Starch and Yeast Company) mixed with $100 \mathrm{~g}$ black honey and the mixture was adjusted to 1 litter with tap water and left for $48 \mathrm{hr}$. The yeast extract was diluted with tap water 10 times and used for foliar application treatments. 
At harvest, the above-ground shoots were recorded. The agronomic benefit of the intercrops was evaluated by the land equivalent ratio (LER) index (Mead and Willey, 1980), using the following formula:

$$
\mathrm{LER}=(\mathrm{Yab} / \mathrm{Yaa})+(\mathrm{Yba} / \mathrm{Ybb})
$$

Where; $\mathrm{Yab}=$ the yield per unit area of crop (a) in the intercrop, $\mathrm{Yba}=$ the yield per unit area of crop (b) in the intercrop, Yaa = the yield per unit area of crop (a) in the solo crop, and $\mathrm{Ybb}=$ the yield per unit area of crop (b) in the solo crop (Ghanbari-Bonjar and Lee, 2002). A LER value greater than 1.0 indicates the positive effect of the intercropping system.

The term "harvest index percentage";( $\mathrm{HI} \%)$ is being introduced to relate the grain yield (GY) to total plant biomass. Accordingly, HI was calculated using the following relation; where SY is the straw yield:

$$
\mathrm{HI}(\%)=\mathrm{GY} /(\mathrm{GY}+\mathrm{SY}) \mathrm{X} 100
$$

Data were subjected to analysis of variance test (ANOVA) and the LSD was calculated to assess the significant differences between treatments, using COSTAT program ( Costat CoHort Software, 1985).

\begin{tabular}{|c|c|c|}
\hline Properties & & Sandy soil \\
\hline \multicolumn{2}{|c|}{$\begin{array}{l}\text { Soil } \mathrm{pH}(1: 2 \text { soil - water }) \\
\text { Total Soluble Salts ( } 1: 2 \text { soil -water }) \text { : }\end{array}$} & 7.35 \\
\hline $\mathrm{EC}$ & $\mathrm{dS} \mathrm{m} \mathrm{m}^{-1}$ & 1.58 \\
\hline $\mathrm{Ca}^{++}$ & meq $L^{-1}$ & 4.1 \\
\hline $\mathrm{Mg}^{++}$ & $"$ & 2.3 \\
\hline $\mathrm{Na}^{+}$ & $"$ & 7.9 \\
\hline $\mathrm{K}^{+}$ & $"$ & 1.5 \\
\hline $\mathrm{CO}_{3}^{--}$ & $"$ & - \\
\hline $\mathrm{HCO}_{3}^{-}$ & $"$ & 2.1 \\
\hline $\mathrm{Cl}^{-}$ & $"$ & 3.9 \\
\hline $\mathrm{SO}_{4}^{-}$ & $"$ & 9.8 \\
\hline Organic matter & $\%$ & 0.14 \\
\hline Total Nitrogen & $\%$ & 0.06 \\
\hline Available $\mathrm{K}$ & $\mathrm{Cmol} \mathrm{Kg}^{-1}$ & 0.97 \\
\hline Available P & $\mathrm{mg} \mathrm{Kg}^{-1}$ & 5.15 \\
\hline Calcuim Carbonate & $\%$ & 0.85 \\
\hline Sand ( 2- $0.05 \mathrm{~mm}$ ) & $\%$ & 93 \\
\hline Silt $\quad(0.05-0.002 \mathrm{~mm})$ & $\%$ & 5 \\
\hline Clay $\quad(<0.002 \mathrm{~mm})$ & $\%$ & 2 \\
\hline Texture & & Sandy \\
\hline
\end{tabular}

Table (1).Chemical and physical properties of the used soils 


\section{RESULTS}

\section{The Performance of Maize Yield Attributes:}

The effect of foliar application of yeast, and cropping system under different water salinity levels on maize yield attributes; expressed as plant height, cob weight, grain (GY) and straw (SY) yields, 1000-grain weight and harvest index percentage ( $\mathrm{HI} \%)$ are presented in (Table 2) Irrespective to the foliar application of yeast and cropping system, (Table 2) showed that maize plants exposed to salinity stress exhibited marked significant decrease on all measured parameters across the water salinity level from 0 to 4 \& $8 \mathrm{dS} / \mathrm{m}$. However, spraying plants with yeast significantly increased only the height of maize plants, associated with negative effects on the other measured parameters (Table 2). In addition, the results revealed that the monoculture crop yielded higher straw and grain records than the corresponding intercropped maize. The estimated advantages in SY and GY for the sole crop were 48.6 and $11.2 \%$, respectively. To the contrary, the results proved that intercropped maize was more superior for mediating the cob weight, 1000-grain weight and $\mathrm{HI} \%$ than the sole crop. On average, the advantages of the concerned traits were, however, limited by $27.3,9$ and $20.7 \%$, respectively. (Table 2 ).

Irrespective to foliar yeast application, the data presented in (Table 3) revealed that all water salinity levels exhibited marked negative effects on the studied parameters. Such effects were, however, more abundant in sole maize crop than the intercropped plant at the same level of salinity or control treatments. Quantitatively, the reduction in maize grain yield accounted for $56.6 \%$ and $55.7 \%$ in sole and intercropped plants at EC $8 \mathrm{dS} / \mathrm{m}$, respectively. Similarly, yeast foliar application significantly increased plant height, SY and GY in control treatments (Table 3), associated with significant increase on the weight of 1000 grain at EC $4 \mathrm{dS} / \mathrm{m}$. Besides, the foliar yeast treatments acted to exert significantly decrements in cob weight in control plants and SY \& GY across all the water salinity levels.

\section{The Performance of Peanut Yield Attributes:}

The data presented in (Figure 1) showed that different salinity levels imposed significant decrement in peanut yield (GY). Relative to the control treatments, the estimated relative decrease in GY was $22 \%$ and $45 \%$ at EC 4 \& $8 \mathrm{dS} / \mathrm{m}$, respectively. Regardless to salinity levels and foliar yeast treatments, the results outlined in (Figure 2) revealed that the intercropped peanut yielded higher grain yield $(153.6 \mathrm{~g} /$ plant $)$ than the corresponding monoculture one (128.1 gm/plant). Moreover, foliar application of yeast exhibited marked significant increases in GY as compared with non-fertilized ones (163.9 \&117.8 $\mathrm{g} /$ plant), respectively (Figure 3 ). The similar results were noted in the weight of 100 peanut seed (Table 4). 
Table (2). Means of the measured agronomic traits recorded on maize plants as affected by water salinity levels, cropping system and spraying with yeast extract as main effects

\begin{tabular}{lcccccc}
\hline Treatment variables & $\begin{array}{c}\text { Plant } \\
\text { Length } \\
(\mathbf{c m})\end{array}$ & $\begin{array}{c}\mathbf{S Y} \\
\left(\mathbf{k g} / \mathbf{m}^{2}\right)\end{array}$ & $\begin{array}{c}\text { Cob } \\
\text { Weight }(\mathbf{g})\end{array}$ & $\begin{array}{c}\mathbf{G Y} \\
\mathbf{( k g / \mathbf { m } ^ { 2 } )}\end{array}$ & $\begin{array}{c}\text { Wt. 1000 } \\
\mathbf{g r a i n}(\mathbf{g})\end{array}$ & $\begin{array}{c}\mathbf{H I} \\
\mathbf{( \% )}\end{array}$ \\
\hline Water Salinity & & & & & & \\
Tap water & 276.5 & 1.55 & 232.4 & 0.928 & 355.8 & 37.7 \\
$4(\mathrm{dS} / \mathrm{m})$ & 247.0 & 1.30 & 184.9 & 0.597 & 315.1 & 31.2 \\
$8(\mathrm{dS} / \mathrm{m})$ & 215.0 & 1.06 & 144.1 & 0.407 & 254.5 & 28.5 \\
LSD, 5\% & 5.56 & 0.10 & 6.89 & 0.04 & 3.64 & 0.89 \\
Foliar yeast & & & & & & \\
Without & 236.0 & 1.48 & 202.9 & 0.732 & 329.5 & 32.5 \\
With & 256.3 & 1.13 & 171.4 & 0.557 & 287.3 & 32.5 \\
LSD, 5\% & 4.54 & 0.08 & 5.62 & 0.03 & 2.97 & 0.72 \\
Cropping system & & & & & & \\
Sole & 234.5 & 1.56 & 164.7 & 0.700 & 295.2 & 29.0 \\
Intercropped(Ic) & 257.7 & 1.05 & 209.6 & 0.588 & 321.7 & 35.9 \\
LSD, 5\% & 4.54 & 0.08 & 5.62 & 0.03 & 2.97 & 0.72 \\
\hline SY= Straw yield, & GY= Grain yield, & HI= Harvest index & &
\end{tabular}

Table (3). Yield components of maize in relation to the interaction effects of water salinity with cropping system and yeast application.

\begin{tabular}{|c|c|c|c|c|c|c|c|}
\hline \multirow[t]{2}{*}{ Treatments } & \multirow{2}{*}{$\begin{array}{c}\begin{array}{c}\text { Water } \\
\text { salinity }\end{array} \\
\mathrm{dS} / \mathrm{m}\end{array}$} & \multicolumn{2}{|c|}{$\begin{array}{l}\text { Cropping } \\
\text { system }\end{array}$} & \multirow{2}{*}{$\frac{\text { LSD }}{5 \%}$} & \multicolumn{2}{|c|}{ Yeast application } & \multirow{2}{*}{$\frac{L S D}{5 \%}$} \\
\hline & & Sole & IC & & without & with & \\
\hline \multirow{3}{*}{ Plant Height, cm } & 0 & 273.0 & 280.0 & \multirow[t]{3}{*}{7.85} & 260.5 & 292.5 & \multirow[t]{3}{*}{7.85} \\
\hline & 4 & 236.0 & 258.0 & & 252.5 & 241.5 & \\
\hline & 8 & 195.0 & 235.0 & & 195.5 & 235.0 & \\
\hline \multirow{3}{*}{$\mathrm{SY}, \mathrm{kg} / \mathrm{m}^{2}$} & 0 & 1.85 & 1.25 & \multirow[t]{3}{*}{0.14} & 1.48 & 1.63 & \multirow[t]{3}{*}{0.14} \\
\hline & 4 & 1.48 & 1.13 & & 1.66 & 0.95 & \\
\hline & 8 & 1.35 & 0.78 & & 1.30 & 0.83 & \\
\hline \multirow{3}{*}{ Cob weight,g } & 0 & 212.9 & 251.8 & \multirow[t]{3}{*}{9.73} & 246.9 & 217.9 & \multirow[t]{3}{*}{9.73} \\
\hline & 4 & 159.3 & 210.4 & & 188.5 & 181.3 & \\
\hline & 8 & 121.8 & 166.5 & & 173.3 & 115.0 & \\
\hline \multirow{3}{*}{$\mathrm{GY}, \mathrm{kg} / \mathrm{m}^{2}$} & 0 & 0.99 & 0.86 & \multirow[t]{3}{*}{0.05} & 0.90 & 0.96 & \multirow[t]{3}{*}{0.05} \\
\hline & 4 & 0.67 & 0.52 & & 0.79 & 0.40 & \\
\hline & 8 & 0.43 & 0.38 & & 0.51 & 0.31 & \\
\hline \multirow{3}{*}{1000 grain wt.,g } & 0 & 342 & 370 & \multirow[t]{3}{*}{5.13} & 411 & 301 & \multirow[t]{3}{*}{5.13} \\
\hline & 4 & 280 & 351 & & 301 & 329 & \\
\hline & 8 & 264 & 245 & & 277 & 232 & \\
\hline \multirow{3}{*}{$\mathrm{HI}, \%$} & 0 & 35.0 & 40.5 & \multirow[t]{3}{*}{1.24} & 37.8 & 37.6 & \multirow[t]{3}{*}{1.24} \\
\hline & 4 & 29.0 & 33.0 & & 31.8 & 30.6 & \\
\hline & 8 & 22.7 & 34.3 & & 27.8 & 29.1 & \\
\hline
\end{tabular}




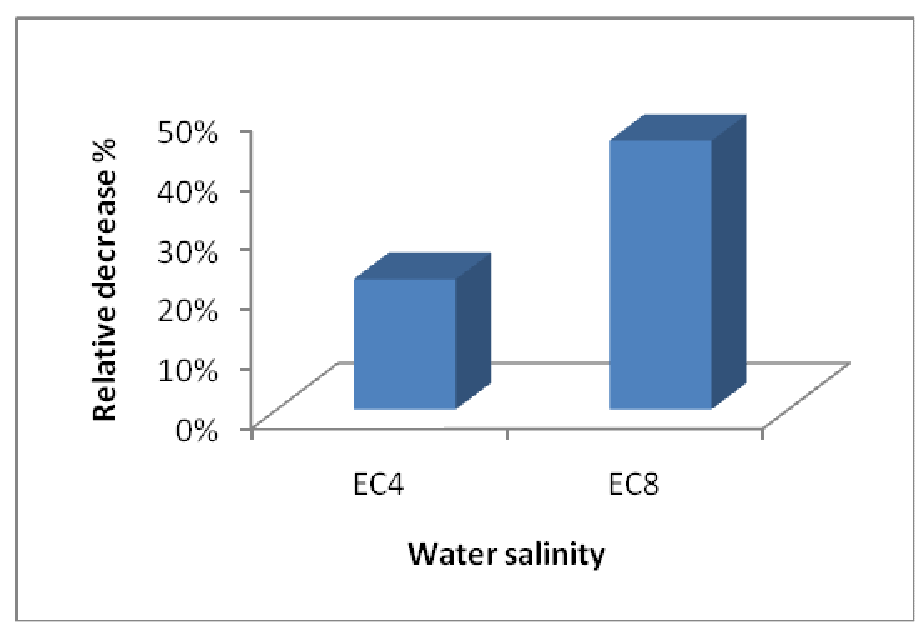

Fig(1). Relative decrease (\%) of Peanut seed yield/plant

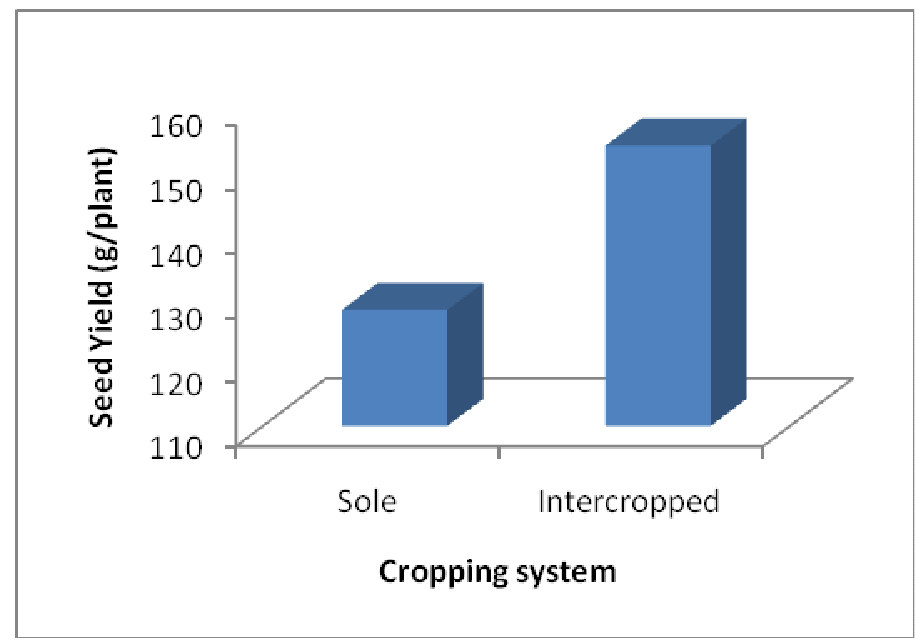

Fig (2). Peanut seed yield (g/plant)

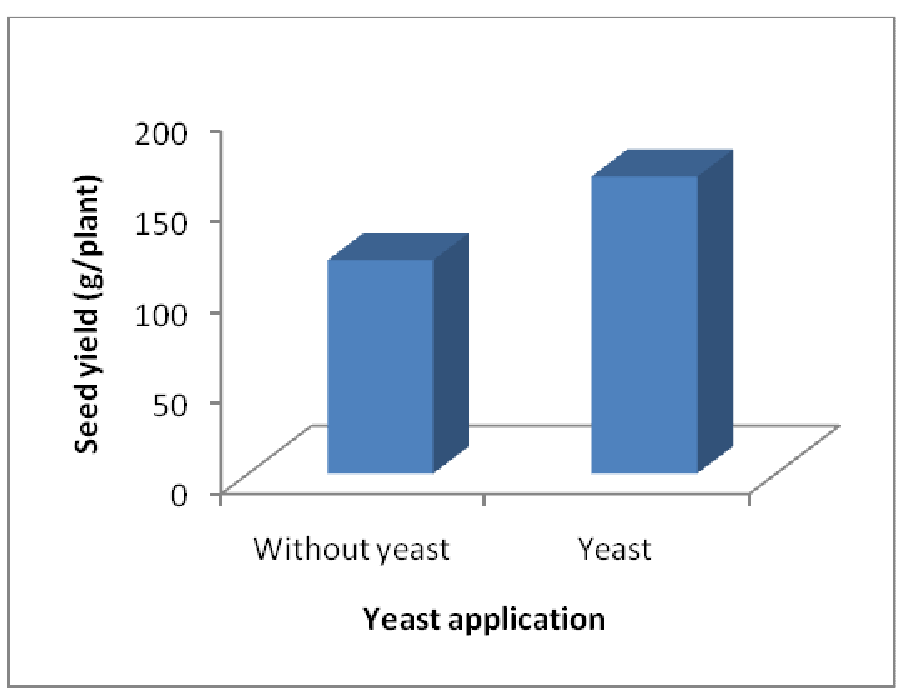

Fig (3). Peanut seed yield (g/plant) 
Table (4).The main effect of water salinity levels, cropping system and yeast application on the peanut yield.

\begin{tabular}{cccc}
\hline Treatment & Seeds weight & $\begin{array}{c}\text { Wt.100 seed } \\
\text { (g/plant) }\end{array}$ & $\begin{array}{c}\text { (g) } \\
\text { Water salinity }\end{array}$ \\
& Tap water & 181.3 & 139.2 \\
& S1 & 141.7 & 100.5 \\
& S2 & 99.6 & 55.8 \\
\multirow{2}{*}{ Cropping system } & L.S.D.(5\%) & 0.016 & 4.82 \\
\hline \multirow{3}{*}{ Yeast application } & Sole & 128.1 & 81.5 \\
& Intercropped & 153.6 & 115.5 \\
& L.S.D.(5\%) & 0.013 & 3.94 \\
\hline S1= ECw 4 dS/m & Without yeast & 117.8 & 84.9 \\
& Yeast & 163.9 & 112.1 \\
& L.S.D.(5\%) & 0.013 & 3.93 \\
\hline
\end{tabular}

The data given in (Table 5) showed that intercropped peanut leads to considerable improvement in peanut yield along the different salinity levels, as compared with the corresponding sole crop, whereas the relative increases accounted for $17.5,18$ and $27.6 \%$ at 0,4 and $8 \mathrm{dS} / \mathrm{m}$, respectively. Moreover, this tendency was also manifested in weight of 100 seed as affected by intercropping system and water salinity levels. Yeast treatment was creative and exhibited marked significant increases in peanut seed yield and 100-seed weight along the concerned salinity levels (Table 5).

The highest relative increase in seed yield was, however, recorded in plants sprayed with yeast, particularly, at the highest water salinity level.

Table( 5). Yield components of peanut in relation to the interaction effects of water salinity with cropping system and yeast application

\begin{tabular}{cccccccc}
\hline \multirow{2}{*}{ Treatments } & $\begin{array}{c}\text { Water } \\
\text { salinity }\end{array}$ & \multicolumn{2}{c}{$\begin{array}{c}\text { Cropping } \\
\text { system }\end{array}$} & LSD & \multicolumn{2}{c}{$\begin{array}{c}\text { Yeast } \\
\text { Application }\end{array}$} & \multirow{2}{*}{ LSD } \\
\cline { 2 - 8 } & $\mathbf{d S / m}$ & Sole & IC & $5 \%$ & without & with & $5 \%$ \\
\hline \multirow{3}{*}{ Seed yield(g/plant) } & 0 & 166.7 & 195.9 & 0.025 & 154.2 & 208.4 & 0.025 \\
& 4 & 130.0 & 153.4 & & 115.9 & 167.5 & \\
& 8 & 87.5 & 111.7 & & 83.3 & 115.8 & \\
\hline \multirow{3}{*}{ Wt 100 seed (g) } & 0 & 103.3 & 175.1 & 6.81 & 130.4 & 148.0 & 6.81 \\
& 4 & 98.0 & 103.1 & & 89.6 & 111.4 & \\
& 8 & 43.2 & 68.5 & & 39.7 & 72.0 & \\
\hline
\end{tabular}




\section{Land equivalent ratio (LER)}

To assess the contribution, land equivalent ratio (LER) is being an important tool for studying and evaluation the intercropping systems. This concept reveals that all other things being equal to measure of the yield advantage obtained by intercropping two or more crops or varieties as compared to the sole of the same crops or varieties. It is worthy to point out that when the LER accounted for 1.0, this means that there aren't differences in yield between the intercrop and the collection of monocultures.

Any value greater than 1.0 revealed the presence of positive interferences among the crops components of the mixture. On the other hand, when any negative interspecific interference is developed, it reveals that the mixture was not as intensive as the interspecific interference that existed in the monocultures. The results presented in (Table 6), proved that $L E R>1$, indicating that the yield advantage of intercropping. The highest significant values of LER were obtained when treated the maize plants with yeast as a main effect. At the higher salinity level (EC $8 \mathrm{dS} / \mathrm{m}$ ), the highest LER accounted (1.53) as compared with other treatments, irrespective to the addition of yeast (Table 6). Our experimental results support the findings by Okpara (2000) in maizecowpea intercrops, which showed yield advantages in the systems. The LER obtained in his study indicated a greater productivity per unit area of land for the mixtures than when either of the two crops was grown separately.

Table (6). Main effects of foliar application of yeast and water salinity levels on the performance of land equivalent ratio (LER) components for grain yield(GY) data of maize/peanut cropping system

\begin{tabular}{lccc}
\hline \multicolumn{1}{c}{ Treatment variables } & Lm & $\begin{array}{c}\text { GY } \\
\text { Lp }\end{array}$ & LER \\
\hline Water Salinity levels & & & \\
Tap water & 0.87 & 0.59 & 1.46 \\
$4(\mathrm{dS} / \mathrm{m})$ & 0.77 & 0.59 & 1.36 \\
$8(\mathrm{dS} / \mathrm{m})$ & 0.89 & 0.64 & 1.53 \\
\hline biofertilizer & & & \\
without & 0.61 & 0.68 & 1.34 \\
with & 1.28 & 0.55 & 1.83 \\
\hline $\mathrm{Lm} \mathrm{\&} \mathrm{L}=$ partial LER for maize \& peanut, respectively
\end{tabular}

\section{DISCUSSION \& CONCLUSION}

Salinity induced serious causes effects on peanut and maize plants. According to FAO (1988), Table (7) presented the yield potential of pervious plants as influenced by irrigation water salinity $\left(E_{w}\right)$ or soil salinity $\left(E C_{e}\right)$ 
Table (7).Crop tolerance and yield potential of Maize \& Peanut as influenced by irrigation water salinity $\left(\mathrm{EC}_{\mathrm{w}}\right)$ or soil salinity $\left(\mathrm{EC}_{\mathrm{e}}\right)$

\begin{tabular}{ccccccccccc}
\hline \multirow{2}{*}{$\begin{array}{c}\text { Field } \\
\text { Crops }\end{array}$} & \multicolumn{2}{c}{$\mathbf{1 0 0 \%}$} & \multicolumn{2}{c}{$\mathbf{9 0 \%}$} & \multicolumn{2}{c}{$\mathbf{7 5 \%}$} & \multicolumn{2}{c}{$\mathbf{5 0 \%}$} & \multicolumn{2}{c}{$\mathbf{0 \%}$} \\
\cline { 2 - 12 } & ECe & ECw & ECe & ECw & ECe & ECw & ECe & ECw & ECe & ECw \\
\hline Maize & 1.7 & 1.1 & 2.5 & 1.7 & 3.8 & 2.5 & 5.9 & 3.9 & 10 & 6.7 \\
Peanut & 3.2 & 2.1 & 3.5 & 2.4 & 4.1 & 2.7 & 4.9 & 3.3 & 6.6 & 4.4 \\
\hline
\end{tabular}

Our experimental data proved that both maize and peanut were moderately sensitive plants whereas the accounted $\mathrm{EC}_{\mathrm{w}}$ that can't produce any yield were about 7 and $4.5 \mathrm{dS} / \mathrm{m}$, respectively. Under our experimental condition, it's evident that cropping system and foliar application with yeast decreased the salinity hazard and improved the salinity tolerance, even at high water salinity level. Obviously, the aforementioned confirmed results that peanut - maize intercropping system was more superior to the sole-cultivated plants. It was creative to improve the carbohydrate and the protein levels for the small farms (Liben et al., 2001). Evidently, the maize-peanut intercropping system is a good alternative mean for the sustainable farming. This finding also agreed quite closely with finding of Lemlem (2013) who indicated that the intercropping of maize-cowpea and maize-lablab was advantageous than monocrop maize. Similar results were reported by Ghosh (2004), indicated that significant yield and monetary advantage were assessed in the case of intercrops of groundnut with maize.

Moreover, the use of yeast as a biofertilizer showed significant positive results to the most of the measured parameters of both maize and peanut plants. Positive effects of yeast were reported in previous works (Mahdi et al., 2010). In agreement with our results, Wali (2010) indicated that yeast has good efficiency on growth characters of wheat plants. The positive effect of yeast is supported by the findings of Mekki and Ahmed (2005), Mirabal et al. (2008) and Hesham and Mohamed (2011).

They explained that the increase in yield components, due to yeast application could be inferred to its effect, on providing surplus available nutrients for the growing plants and promoted the regulation of regulators such as auxins, gibberellins, cytokinins, and vitamins that are essentially required for growth yield production. Agamy et al. (2013) reported that the application of saccharomyces sp.enhanced the formation of photosynthetic pigments (chlorophyll $\mathrm{a}$ and $\mathrm{b}$ ).

So, we assume that maize-peanut intercropping system is a good alternative of cropping system in the sustainable farming in salt-affected soils in presense of yeast. 


\section{REFERENCES}

Agamy, R., M. Hashem and S.Alamri. (2013). Effect of soil amendment with yeasts as bio-fertilizers on the growth and productivity of sugar beet. Afr. J. Agric .Res., 8(1): 46-56.

Al-Falih, A.M. (2006). Nitrogen transformation in vitro by some soil yeasts. Saudi. J. Biol. Sci., 13(2):135-140.

Al-Falih, A.M. and M.Wainwright. (1995). Nitrification, S oxidation and P solubilization by the soil yeast Williopsis californica and by Saccharomyces cerevisiae. Mycol. Res., 99:200-20

Altieri, M.A. (1999). The ecological role of biodiversity in agroecosystems. Agr Ecosyst Environ, 74:19-31.

Black C. A.(1965). Methods of soil analysis. Chemical and Microbiological properties. U.S.A., 2: 1149-1163.

Boraste, A., K.K. Vamsi , A. Jhadav , Y. Khairnar ,N. Gupta, S. Trivedi, P. Patil, G. Gupta, M. Gupta, A.K. Mujapara and B. Joshi. (2009). Biofertilizers: A novel tool for agriculture. Int. J. Microbiol. Res., 1(2):23-31.

Bouyoucos, H.H. (1951). Recalibration of the hydrometer for making mechanical analysis of soil, Agron. Jour., 43:434-438.

Cloete, K, A. Valentine, M. Stander, L. Blomerus and A. Botha.(2009). Evidence of symbiosis between the soil yeast Cryptococcus laurentii and a sclerophyllous medicinal shrub, Agathosma betulina (Berg.) . Pillans. Microb. Ecol., 57:624632.

Costat CoHort Software Version 3.0 (1985). User's Manual , Tusson, Arizona,U.S.A. .

El-Tarabily, K.A. and K. Sivasithamparam. (2006). Potential of yeasts as biocontrol agents of soil-borne fungal plant pathogens and as plant growth promoters. Mycoscience, 47:25-35.

FAO.(1988). Salt-affected soils and their management, (39): 143

Ghanbari-Bonjar, A. and H. C. Lee. (2002). Intercropped wheat (Triticum aestivum L.) and bean (Vicia faba L.) as a whole-crop forage: effect of harvest time on forage yield and quality. Grass and Forage Science, 5:2836.

Ghosh, P.K. (2004). Growth, yield, competition and economics of groundnut/cereal fodder intercropping systems in the semi-arid tropics of India. Field Crops Res., 88:227-237.

Hesham, A.L. and H. Mohamed. (2011). Molecular genetic identification of yeast strains isolated from Egyptian soils for solubilization of inorganic phosphates and growth promotion of corn plants. J. Microbiol. Biotechnol., 21:55-61

Lemlem, A. (2013). The effect of intercropping maize with cowpea and lablab on crop yield. Herald Journal of Agriculture and Food Science Research, 2 (5):156 - 170.

Li, L. , F.S.Zhang, X.L. Li. P. Christie, J.H. Sun, S.C. Yang and C. Tang . (2003). Inter specific facilitation of nutrient uptake by intercropped maize and faba bean. Nutrient Cycling in Agro eco., 68: 61-71.

Liben, M., T. Tadesse and A. Assefa. (2001). Determination of nitrogen and phosphorus fertilizer levels in different maize- faba bean intercropping 
patterns in northwestern Ethiopia. $7^{\text {th }}$ Eastern and Southern Aferica Regional Maize Conference, 513-518.

Lithourgidis, A.S., C.A. Dordas, C.A. Damalas and D.N. Vlachostergios (2011). "Annual intercrops: an alternative pathway for sustainable agriculture". Australian Journal of Crop Science, 5 (4): 396-410.

Mahdi, S.S., G.I. Hassan, S.A. Samoon , H.A. Rather, A.D.Showkat, and B.Zehra. (2010). Bio-fertilizers in organic agriculture. J. Phytol., 2(10):4254.

Mead, R. and R. W. Willey. (1980). The concept of 'a land equivalent ratio and advantages in yield from intercropping. J. Exp. Agr., 16:217-228.

Mekki, B.B. and A.G.Ahmed. (2005). Growth, Yield and See Quality of Soybean (Glycine max L.) As Affected by Organic, Bio-fertilizer and Yeast Application. Res. J. Agric. Bio. Sci.,1 (4):320-324.

Mirabal, A. L., D. Kleiner and E. Ortega. (2008). Spores of the mycorrhizal fungus Glomus mosseae host yeasts that solubilize phosphate and accumulate polyphosphates. Mycorrhiza, 18:197-204.

Moreira, N. (1989). The effect of seed rate and nitrogen fertilizer on the yield and nutritive value of oat-vetch mixtures. J. Agric. Sci. Camb.,112 (1):5766.

Mpairwe, D.R., E.N.Sabiiti, N.N.Ummuna, A.Tegegne and P.Osuji. (2002). Effect of intercropping cereal crops with forage legumes and source of nutrients on cereal grain yield and fodder dry matter yields. Afr. Crop. Sci. J, 10: 81-97.

Nassar, A., K. El-Tarabily and K. Sivasithamparam. (2005). Promotion of plant growth by an auxin-producing isolates of the yeast Williopsis saturnus endophytic in maize (Zea mays L.) roots. Biol. Fert. Soils., 42:97108.

Okpara, D. A. (2000). Effect of the time of introduction of component crop and fertilizer- $\mathrm{N}$ application. on maize and vegetable cowpea grown in mixtures under the humid tropical conditions. J. Tropical Agric., Food, Environ. Extension, 2: 65-73

Omran, Y.A., (2000). Studies on histophysiological effect of hydrogen cyanamide (Dormex) and yeast application on bud fertility, vegetative growth and yield of "Roumi Red"' grape cultivar. Ph. D. Thesis, Fac of Agric Assiut Univ Egypt.

Ouma, G. and P. Jeruto (2010). "Sustainable horticultural crop production through intercropping: The case of fruits and vegetable crops: A review". Agriculture and Biology Journal of North America, 1 (5): 1098-1105.

Page,A.L. (1982). Methods of soil analysis. Chemical and Microbiological properties. U.S.A.: Second Edition, 9(2) : 323-332

Richards, A.L. (1954). Saline and alkali soils. Agriculture handbook 60, U.S.Dept. of Agriculture ; 94

Wali, A.M.A. (2010). The combined Effect of mineral organic and biofertilizers on the productivity and quality of some wheat cultivars. Ph.D. Thesis, Fac. Agric. Alex. Univ., Egypt.

Watanabe F.S. and S.R. Olsen. (1965). Test of an ascorbic acid method for determining phosphorus in water and $\mathrm{NaHCO}_{3}$ extracts from soil, Soil Sci. Soc. Amer., $29: 677-680$ 
الملخص العربى

تأثير الرش بالخميرة على نمو الذرة المحملة مع الفول السودانى المروية بمياه ملحية

\author{
منى جميل عطية وأميرة أحمد محمد العزبى \\ قسم بحوث الأراضى الملحية والقلوية - معهد بحوث الأراضى والمياه والبيئة - مركز البحوث الزراعية \\ الأسكندرية - جمهورية مصر العربية
}

أجريت هذه الدراسة لتقيم تأثير الرش بالخميرة على النمو الخضرى لمحصول الذرة والفول السودانى المنزرعين منفردين وكذا المنزرعين محملين معا تحت ظروف الرى بمياه ملحية .

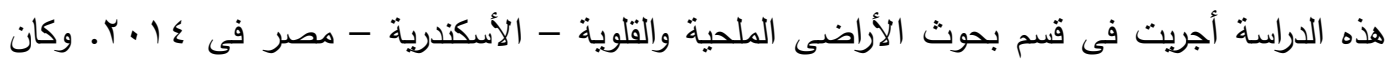
التصميم الأحصائى للتجربة هو القطاعات العشوائية الكاملة ويشمل ب عوامل بمستوياتها وكررت جميع المعاملات

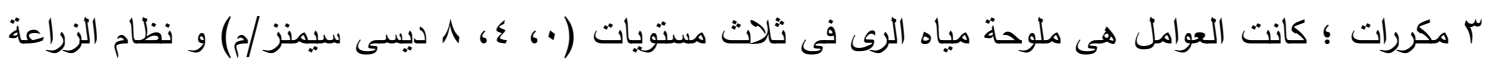

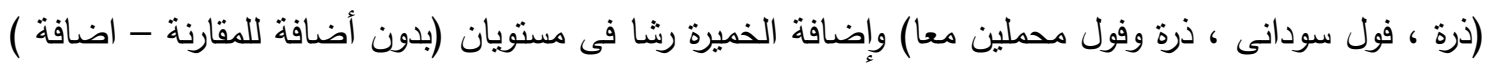

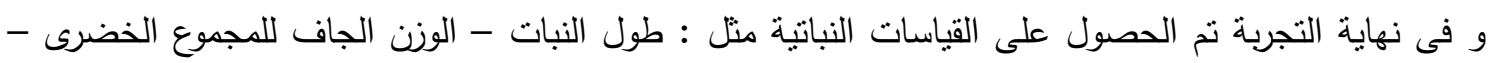

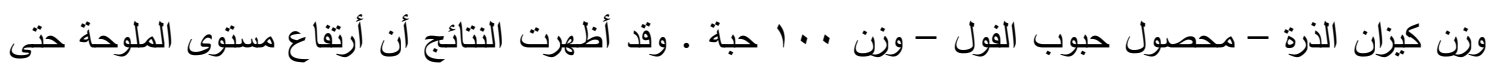

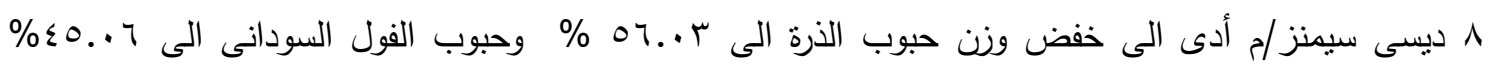
مقارنة بمعاملة الكنترول ـ أما بخصوص نظام الزراعة فقد اظهرت النتائج أن نظام التحميل أعطى أعلى محصول

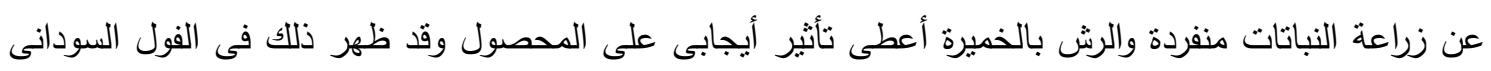
أكثر من الذرة مقارنة بمعاملات الكنترول . 